\title{
IMPACT OF FAMILY INCOME AND SIZE ON PER CAPITA SOLID WASTE GENERATION: A CASE STUDY IN MANMUNAI NORTH DIVISIONAL SECRETARIAT DIVISION OF BATTICALOA
}

\section{K. SIVAKUMAR ${ }^{1}$ AND M. SUGIRTHARAN ${ }^{2}$}

\section{${ }^{1}$ Department of Agricultural Engineering, Faculty of Agriculture, Eastern University, Vantharumoolai, Chenkalady, Sri Lanka \\ ${ }^{2}$ Department of Agricultural Engineering, Faculty of Agriculture, Eastern University, Vantharumoolai, Chenkalady, Sri Lanka}

\begin{abstract}
The generation of solid waste has become an increasing environmental and public health problem everywhere in the world, especially in developing countries. The rate of generation of solid waste in the society is increasing with an increase of population, technological development, and the changes in the life styles of the people. As family size and income are the most significant factors affecting the quantity of solid waste from household consumption, a study on the relationship among these is vital in the decision making on waste management strategies. Therefore, a study was conducted at Manmunai North Divisional Secretariat areas of Batticaloa district to find out the correlation among residential solid waste generation, family size and income. The household sector is one of the primary sources of solid wastes in the study area. This study covered 100 houses with different socioeconomic levels such as income level and family size. There were six components of solid waste; food waste, paper, polyethylene, plastic, glass and metal which were evaluated in this study.

Present study revealed that residential solid waste generation showed nonsignificant positive correlation $(r=0.184, p>0.05)$ with monthly income whereas significant positive correlation $(r=0.476, p<0.01)$ was found with the family size. Based on monthly income, generation of food, paper, plastic and glass waste showed non-significant positive correlation while non-significant negative correlation was found with polyethylene waste. Further, residential waste generation such as food, paper, plastic and metal showed significant positive correlation with family size
\end{abstract}


whereas generation of glass and polyethylene waste showed non-significant positive correlation with family size.

Keywords: Family size, Food waste, Income level, Plastics, Solod waste

\section{INTRODUCTION}

Solid wastes are the materials which arise from various human and animal activities and discarded as useless or unwanted (Rana, 2007). Solid waste generation is an inevitable consequence of production and consumption activities in any economy (Eugenia et al., 2002). UNEP (2005) also reported that fast expansion of urban, agricultural and industrial activities spurred by rapid population growth has produced a huge amount of solid waste that pollutes the environment and destroy resources. Globally the per capita amounts of municipal solid waste generated on a daily basis vary significantly (WRI, 1996). Globalization can promote economic growth, a desirable outcome. However, this economic growth in addition to population increase and urbanization will seriously strain municipal resources to deal with booming amounts of wastes (Medina, 2002).

Solid waste generation depends on the economy of the people and level of income of the family or individual. Previous studies have shown that for every Indian, an increase in income by Rs. 1000 results in an increase of solid waste generation by one kilogram per month. It is a common observation that with an increase of economic growth the waste generation grows in an equal manner. Economic growth and waste generation have not been decoupled in both developing and industrialized world (Visvanathan \& Trankler, 2006). Medina (2002) also reported that a positive correlation tends to exist between a community's income and the amount of solid waste generated. Wealthier individuals consume more than lower-income ones, which result in a higher waste generation rate for the former. Income and household size are the most significant factors affecting the quantity of solid wastes from household consumption (Richardson \& Havlicek, 1974). Visvanathan \& Trankler (2003) reported that in a family with rich socioeconomic condition, daily waste generation rates were generally higher than the lower socioeconomic families.

Solid waste disposal is one of the major issues in Manmunai North (MN) area of Batticaloa. NECCDEP (2008) reported that about 60 to 80 tons solid waste are generated per day in MN area and from this only 40 to 45 tonnes are collected for 
disposal. Enormous amounts of solid wastes are generated from various sources such as household, markets, commercial establishments and institutions including schools, hospitals and government offices in the MN area of Batticaloa. However, this study only deals with household sector in order to find out correlation between solid waste generation and socioeconomic factors such as income level and family size. The principal hypothesis of this study is that residential waste generation increases with increasing family size and income.

The objectives of this investigation were to determine the followings;

1. To identify the types of solid waste generated at household level in the Manmunai North (MN) area of Batticaloa;

2. To assess the quantity and composition of residential solid waste generated in the MN area; and

3. To find out the correlation among household solid waste generation, income level and family size.

\section{MATERIALS AND METHODS}

The study was conducted in the Manmunai North DS division of Batticaloa (Fig. 1) from 1 August to 30 September, 2008. At the initial stage of this study, a questionnaire survey was carried out among 150 randomly selected households within the MN area of Batticaloa to get primary data about their income and other information required for this study such as number of household members, methods of waste disposal and types of solid waste being generated from their houses. Based on this information, 100 households were selected by using stratified random sampling method to get the uniform number of samples in the study locations within Manmunai North DS divisions. Variation in income level, number of household members and types of solid waste being generated were also considered for the selection of households for this study.

Bags were issued to each family ( 6 bags/family) for the collection of different types of solid waste such as food waste, paper, polyethylene, plastic, glass and metal. All families were instructed to collect these different types of solid waste in separate bags. Collected solid wastes were weighed at regular intervals. Food waste was weighed daily and other types of waste were weighed once a week for a period of two months (August to September, 2008). Collected data were tabulated and average amounts of different types of waste generated in a month were determined. Collected 
data were statistically analyzed using SPSS for Windows software package to find out the correlation among solid waste generation, income level and family size.

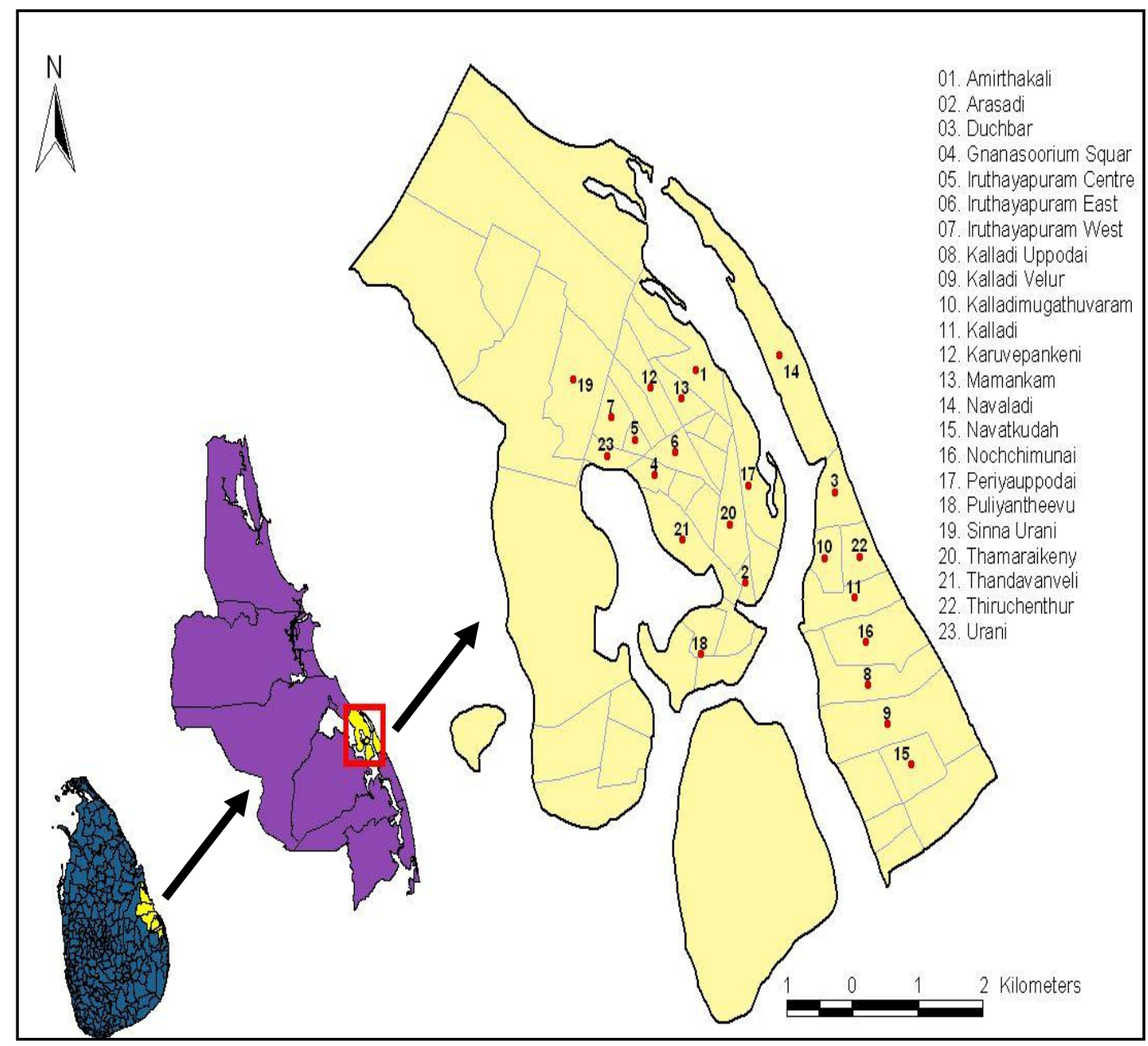

Figure 1: Locations of study at Manmunai North Divisional Secretariat Division of Batticaloa

\section{RESULTS AND DISCUSSION}

\section{Socioeconomic factors considered in the study}

\section{(a) Income level}

Income level was one of the major socioeconomic factors considered in the selection of households. The income level of the society was divided into six major categories. Table 1 shows the number of families falling into each category. 
Table 1: Frequency distribution of various income levels at study area

\begin{tabular}{rc}
\hline $\begin{array}{c}\text { Income Level } \\
\text { (SL Rupees) }\end{array}$ & $\begin{array}{c}\text { Frequency Distribution } \\
\text { (Number of families) }\end{array}$ \\
\hline $5000-10,000$ & 0 \\
$10,000-15,000$ & 10 \\
$15,000-20,000$ & 18 \\
$20,000-25,000$ & 22 \\
$25,000-30,000$ & 24 \\
Above 30,000 & 26 \\
\hline
\end{tabular}

According to Table 1, majority of the families are getting high income level (> SL Rs. 30,000) whereas none of the families have reported a lowest income level (i.e., < SL Rs. 10,000).

\section{(b) Family size}

Based on questionnaire survey, 100 households were selected with vast variation in family size. Table 2 shows the frequency distribution and percentage of household members per family for each category.

Table 2: $\quad$ Frequency distribution of household members in the study area

\begin{tabular}{cc}
\hline $\begin{array}{c}\text { Number of Household } \\
\text { Members/Family }\end{array}$ & $\begin{array}{c}\text { Frequency } \\
\text { Distribution }\end{array}$ \\
\hline Two & 6 \\
Three & 20 \\
Four & 30 \\
Five & 28 \\
Six & 16 \\
\hline
\end{tabular}

\section{Residential solid waste generation in study area}

Table 3 shows the mean total waste generation per month among 100 households studied, waste generation per household per month, composition of different types of wastes generated and per capita waste generation for each type. 
Table 3: $\quad$ Residential solid waste generation in the $\mathrm{MN}$ area of Batticaloa

\begin{tabular}{lcccc}
\hline $\begin{array}{l}\text { Types } \\
\text { Waste }\end{array}$ & $\begin{array}{c}\text { Mean waste } \\
\text { generation/Month } \\
(\mathbf{k g})\end{array}$ & $\begin{array}{c}\text { Mean waste } \\
\text { generation/ } \\
\text { Household/ } \\
\text { day }(\mathbf{k g})\end{array}$ & $\begin{array}{c}\text { Composition } \\
\mathbf{\%}(\mathbf{w t})\end{array}$ & $\begin{array}{c}\text { Mean waste } \\
\text { generation/ } \\
\text { person/ } \\
\text { day }(\mathbf{k g})\end{array}$ \\
\hline Food waste & 3401.54 & 1.13 & 87.95 & 0.26 \\
Paper & 139.30 & 0.05 & 3.60 & 0.01 \\
Glass & 90.10 & 0.03 & 2.14 & 0.01 \\
Polyethylene & 82.90 & 0.03 & 1.86 & 0.01 \\
Metal & 81.90 & 0.03 & 2.33 & 0.01 \\
Plastic & 71.82 & 0.02 & 2.12 & 0.01 \\
Total & 3867.56 & 1.29 & 100.0 & 0.31 \\
\hline
\end{tabular}

As shown in Table 3, mean total waste generation from hundred households was $3867.56 \mathrm{~kg} /$ month. Food waste generation $(3401.54 \mathrm{~kg})$ was greater than other types of waste whereas plastic waste generation was very much lower $(71.82 \mathrm{~kg})$ than all other types of waste studied in this area. Based on these results, every person generates $260 \mathrm{~g}$ of food waste per day and food waste contributes nearly $88 \%$ of the total waste generated in the study area. Average waste generation per household and per capita waste generation were $1.29 \mathrm{~kg} /$ day and $0.31 \mathrm{~kg} /$ day respectively.

\section{Composition of residential solid waste in study area}

Income level, economic growth and lifestyle have strong influence on Municipal Solid Waste (MSW) composition (Zhu et al., 2008). Benjamin \& Mansoor (2004) have revealed that MSW quantity and composition analysis is fundamental for the planning of municipal waste management services. The composition dictates the technology needed for waste processing prior to disposal (NRI, 2003).

It was observed that the food waste is usually the predominant component in the waste stream due to the habit of fresh food consumption and composition of all other types of waste are low in all households studied (Table 3). Visvanathan (2006) also found that food wastes dominate over the major portion of the waste generated in most developing countries in Asia like China, India, Sri Lanka, and Thailand. Similarly, study conducted by NRI (2003) reported that average compositions of the 
solid waste in Batticaloa district were $57.4 \%$ biodegradable, $17.12 \%$ wood, $16.45 \%$ paper, $8.26 \%$ plastic and polyethylene, $2.9 \%$ metal and $2.2 \%$ glass. The overall socio-economic condition of the MN area is also very much responsible for the very high percentage of organic component.

Further, this study revealed that the percentage of recyclables like paper, polyethylene, plastic, glass and metal were small in all locations. Metal and glass waste generation are more or less same when compared to the previous study results (NRI, 2003). In the study area, local scavengers pick up scrap metal and glass on a regular basis and return to recycling centres.

Table 4: Correlation Coefficients among income level, family size and different types of solid waste generated

\begin{tabular}{lcc}
\hline Type of waste & Monthly income & $\begin{array}{c}\text { Number of Household } \\
\text { Members }\end{array}$ \\
\hline Food waste & 0.173 & $0.459^{* *}$ \\
Paper & 0.032 & $0.311^{*}$ \\
Polyethylene & -0.064 & 0.067 \\
Plastic & 0.201 & $0.395^{* *}$ \\
Glass & 0.233 & 0.235 \\
Metal & $0.308^{*}$ & $0.371^{* *}$ \\
\hline Average waste generation/ & 0.184 & $0.476^{* *}$ \\
Household/Month & & \\
& & \\
$*$ & $\quad$ Significant at 5\% probability level \\
$* * \quad=\quad$ Significant at 1\% probability level
\end{tabular}

\section{Correlation between household waste generation and total monthly income}

Correlation study has revealed that although not significant at $5 \%$ probability level, the household waste generation is positively correlated with monthly income ( $\mathrm{r}$ $=0.184, p>0.05)$ i.e. household waste generation is increasing with increasing household income (Table 4). Beukering \& Sehker (1999) also reported that a positive relationship existed between income levels and waste generation at the household level. 


\section{K Sivakukar et al.}

There may be several reasons for non-significant positive correlation. It might have happened due to number of household members, getting food items from outside and reusing some types of waste. Many research findings pointed out that generally waste generation increases as income rises. The most important factor affecting this correlation is number of household members. For example, in some families income level was high but, waste generation was low. Less number of members in that family may be the reason for this condition. Most of the people (about 70\%) living in study area are government servants/employees in private company or NGO/labours/students. These people used to have their breakfast/lunch in canteens/hotels/ neighbour's home. This activity reduces waste generation in their homes. In many households, peoples reuse some types of waste such as glass (e.g., bottles), plastic (e.g., cans, pipes), paper (e.g., news paper, cardboard boxes) and polyethylene bags. About $10 \%$ of people in study area sell bottles/ papers/ metal items to local scavengers or shops and earn income. These situations might be the reasons for non-significant correlation between income and waste generation.

\section{Correlations between total monthly income and types of waste generated}

Positive correlations between monthly income and types of waste generated were evident for food $(r=0.173, p>0.05)$, paper $(r=0.032, p>0.05)$, plastic $(r=$ $0.201, \mathrm{p}>0.05)$ and glass $(\mathrm{r}=0.233, \mathrm{p}>0.05)$ but, they were not significant at $5 \%$ level.

There was non-significant negative correlation $(\mathrm{r}=-0.064, \mathrm{p}>0.05)$ between polyethylene waste and total monthly income. It denotes that as household income increases polyethylene waste generation decreases. Duminda \& Prasansa (2005) also revealed that family income is negatively related to usage of shopping (carry bag) bag. The main reason for the negative correlation is reusing of polyethylene waste. Nearly $40 \%$ of people living in study area reuse polyethylene wastes. This activity reduces the polyethylene waste generation in their houses. However, a significant positive correlation $(\mathrm{r}=0.308, \mathrm{p}<0.05)$ was found with metal waste generation. Increase in income leads to increase in consumption of goods, which may have resulted in an increase in metal waste generation. 


\section{Correlation between household waste generation and family size}

Family size is an important determinant in household waste production (Ghorbani et al., 2007). In the present study too, a significant positive correlation ( $\mathrm{r}$ $=0.476, \mathrm{p}<0.01)$ was found between household waste generation and family size.

\section{Correlation between family size and different types of waste generated}

Family size had significant positive correlations with food $(r=0.459, p<0.01)$, paper $(r=0.311, p<0.05)$, plastic $(r=0.395, p<0.01)$ and metal $(r=0.371, p<0.01)$ waste generation. This is obviously due to the reason that increase in household members leads to increase in resource consumption resulting increase in waste generation at their houses.

However, glass $(r=0.235, p>0.05)$ and polyethylene $(r=0.067, p>0.05)$ waste generation showed non-significant positive correlation with family size. The main reason for this relationship may be due to the reuse of polyethylene and waste glasses.

\section{Household attitudes and participation on waste segregation process}

Participation in solid waste segregation was somewhat erratic in some families. They did not bother to spend time in segregating their residential waste in a proper manner. Some types of waste were mixed with other type of waste, for an example paper wastes were mixed with food waste. Majority of the residents (about 60\%) expressed their inadequate knowledge regarding solid waste management. Some participants $(15 \%)$ felt that waste segregation would be a time consuming task. Therefore, awareness must be created about waste segregation procedure at household level and its benefits to protect the environment.

\section{CONCLUSIONS}

This study indicated that the quantity and characteristics of waste are two major important factors in designing the cost effective and environmentally compatible waste management system. The food waste is identified as the predominant waste in entire study area. Hence, there is a possibility to adopt environmentally friendly waste management practices such as compost making at household level due to the higher generation of biodegradable wastes. Residential solid waste generation has shown positive relationship with family income and size. 
Food, paper, plastic, metal and glass waste generation increases with an increasing income level whereas polyethylene waste generation decreases with increasing income level. Further, residential waste generation increases with increasing family size.

\section{ACKNOWLEDGEMENTS}

We wish to express my sincere gratitude all people who had participated and gave support to carry out our study at the Manmunai North DS areas of Batticaloa. We would like to express our deep sense of gratitude to IRQUE-QEF Grant Project and American Institute for Sri Lankan Studies for providing financial assistance to complete this study successfully.

\section{REFERENCES}

Benjamin, B. \& A. Mansoor. 2004. Sampling household waste at source. Journal of Waste Management and Research 22(3): 142-148.

Beukering, P. V. \& M. Sehker. 1999 . Analyzing Urban Solid Waste in Developing Countries. A Perspective in Bangalore, Working Paper No 24, India. pp 46-67.

Duminda, K. \& K. Prasansa. 2005. The problem of solid waste: A case study of the Maharagama local authority. Journal of National Science Foundation 33(1): 51-53.

Eugenia, C. B., N. Georgina \& L. Ramil. 2002. Solid Waste Segregation and Recycling in Metro Manila: Household Attitudes and Behaviour. Resources, Environment and Economics Center for Studies, Philippines. pp 45-67.

Medina, M. 2002. Globalization, Development and Municipal Solid Waste Management in Third World Cities. Institute of Advance Studies, Mexico. pp $1-23$.

National Research Institute. 2003. Municipal Solid Waste Management in Sri Lanka. Country Report, National Research Institute, Sri Lanka. pp 35-47.

North East Coastal Community Development Project. 2008. Preparation of Initial Environmental Examination Report and Detail Design for the Proposed Composting Plant and to the Improvement of Existing Dumping Site at Thirupperunthurai in Batticaloa District. NECCDEP. pp 1-5.

Rana, S.V.S. 2007. Environmental Pollution. Narosa Publishing House, New Delhi. pp. 81-84. 
Richardson, R.A. \& J. Havlicek. 1974. An analysis of seasonal household waste generation. Southern Journal of Agricultural Economics. 06(02): 143-153.

United Nations Environment Programme. 2005. Selection, Design and Implementation of Economic Instruments in the Solid Waste Management Sector in Kenya. United Nations Environment Programme, Nairobi. pp 157163.

Visvanathan, C. 2006. Solid Waste Management in Asian Perspectives. Asian Institute of Technology, Bangkok pp 1-7.

Visvanathan, C. \& J. Trankler. 2003. Municipal Solid Waste Management in Asia: A Comparative Analysis. Proceedings of Workshop on Sustainable Landfill Management, 3-5 December, 2003, Chennai. pp 3-15.

Visvanathan, C. \& J. Trankler. 2006. Municipal Solid Waste Management in India : A Comparative Analysis. Asian Institute of Technology, Bangkok. pp 1-11.

World Resource Institute. 1996. The Urban Environment. Oxford University Press. Oxford. pp. 126-135.

Zhu, D., P.U. Asnani, C. Zurbrugg, S. Anapolsky \& S. Mani. 2008. Improving Municipal Solid Waste Management in India. World Bank, Washington. pp 18. 
K Sivakukar et al. 